Article

\title{
Complementary Biomarker Assessment of Components Absorbed from Diet and Creatinine Excretion Rate Reflecting Muscle Mass in Dialysis Patients
}

\author{
Adrian Post*(D), Akin Ozyilmaz, Ralf Westerhuis, Karin J. R. Ipema, Stephan J. L. Bakker(D) and \\ Casper F. M. Franssen 1 \\ Department of Nephrology, University Medical Center Groningen, University of Groningen, \\ 9713 GZ Groningen, The Netherlands; a.ozyilmaz@umcg.nl (A.O.); r.westerhuis@umcg.nl (R.W.); \\ k.ipema@umcg.nl (K.J.R.I.); s.j.l.bakker@umcg.nl (S.J.L.B.); c.f.m.franssen@umcg.nl (C.F.M.F.) \\ * Correspondence: a.post01@umcg.nl; Tel.: +31-649653442
}

Received: 29 October 2018; Accepted: 20 November 2018; Published: 26 November 2018

check for updates

\begin{abstract}
To prevent protein energy malnutrition (PEM) and accumulation of waste products, dialysis patients require diet adjustments. Dietary intake assessed by self-reported intakes often provides biased information and standard 24-h urinary excretion is inapplicable in dialysis patients. We aimed to assess dietary intake via a complementary, less biased biomarker method, and to compare this to dietary diaries. Additionally, we investigated the prospective association of creatinine excretion rate (CER) reflecting muscle mass with mortality. Complete intradialytic dialysate and interdialytic urinary collections were used to calculate 24-h excretion of protein, sodium, potassium, phosphate and creatinine in 42 chronic dialysis patients and compared with protein, sodium, potassium, and phosphate intake assessed by 5-day dietary diaries. Cox regression analyses were employed to investigate associations of CER with mortality. Mean age was $64 \pm 13$ years and $52 \%$ were male. Complementary biomarker assessed (CBA) and dietary assessed (DA) protein intake were significantly correlated $(r=0.610 ; p<0.001)$, but there was a constant bias, as dietary diaries overestimated protein intake in most patients. Correlations were found between CBA and DA sodium intake $(r=0.297 ; p=0.056)$, potassium intake $(r=0.312 ; p=0.047)$ and phosphate uptake/intake $(r=0.409 ; p=0.008)$. However, Bland-Altman analysis showed significant proportional bias. During a median follow-up of 26.6 (25.3-31.5) months, nine dialysis patients (23\%) died. CER was independently and inversely associated with survival (HR: 0.59 (0.42-0.84); $p=0.003$ ). Excretion measurements may be a more reliable assessment of dietary intake in dialysis patients, as this method is relatively free from biases known to exist for self-reported intakes. CER seems to be a promising tool for monitoring PEM.
\end{abstract}

Keywords: dialysis; dietary diaries; excretion; sodium; potassium; phosphate; protein; creatinine; protein energy malnutrition

\section{Introduction}

For hemodialysis patients, managing nutritional intake presents many challenges. While in the general population overnutrition is an increasing problem, in dialysis patients, protein energy malnutrition (PEM) is a major threat. Surveys show that PEM is highly prevalent (25-50\%) and is considered the most important risk factor for morbidity and mortality in dialysis patients [1-3]. Among the criteria for PEM are loss of muscle mass and insufficient protein intake, and it is for these reasons that dieticians advise a high protein intake in dialysis patients [1]. This advice is, however, 
complicated by the fact that dialysis patients at the same time require their diet to be restricted in the intake of sodium, potassium and phosphate, to prevent development of volume overload, hypertension, hyperkalemia and hyperphosphatemia, all of which are known to adversely affect prognosis [1,2,4-7]. The complexity of this need for a high protein intake on the one hand and restrictions on sodium, potassium and phosphate intake on the other makes for difficult dietary advice, where PEM is continuously lurking. To be able to prevent the occurrence of PEM, volume overload, hypertension, hyperkalemia and hyperphosphatemia, there is a great need for methods that allow for objective evaluation of absorbed dietary components. Classic dietary assessment can be done via diaries on dietary intake, but such assessments have many limitations, including underreporting, overreporting, illiteracy and motivation requirements, changes in diet due to self-reflections, errors in portion size estimates, and socially desirable answers [8-10]. Additionally, dietary diaries give no information on bioavailability, i.e. the absorbed fraction of the ingested dietary components. In subjects who do not depend on dialysis for renal replacement therapy, the gold standard for unbiased assessment of the intake of several components of the diet, including intake of sodium, potassium and protein, is via measurement of sodium, potassium and urea, respectively, in $24 \mathrm{~h}$ urine collections [8,11-15]. For phosphate, assessment via $24 \mathrm{~h}$ urine collection provides an estimate of the amount of phosphate absorbed from the gut becoming available for metabolism [16].

Since dialysis patients primarily depend on hemodialysis for the removal of water-soluble solutes like sodium, potassium, urea and phosphate, $24 \mathrm{~h}$ urinary excretion alone is not a reliable reflection of dietary intake or uptake from the gut. However, if data on $24 \mathrm{~h}$ urine collection would be complemented with data on dialysate collected during a dialysis session, this would provide an alternative which is equivalent to $24 \mathrm{~h}$ urine collection in subjects who do not depend on dialysis.

Interestingly, with the focus of nutrition in dialysis patients on protein energy malnutrition and preservation of muscle mass, it is relevant to note that assessment of creatinine excretion via $24 \mathrm{~h}$ urine collection is considered a reliable method for assessment of muscle mass in subjects not dependent on dialysis, and in previous studies in these subjects we have shown that low creatinine excretion is a very strong predictor of poor long-term outcome, with predictive strength increasing with increasing vulnerability of the population [17-22].

We aimed to investigate the potential utility of collection of the total dialysate solution during hemodialysis, which is complementary to a complete interdialytic urine collection for providing complementary information on dietary intake and dietary uptake of phosphate from the gut for guidance of dietary advices and for the prevention of PEM and other adverse effects in dialysis patients. We hypothesized that even if dietary intake would be assessed optimally from the perspective of dietary diaries, because of the bias intrinsic to diaries [8-10], there would be significant differences and significant bias between the data obtained by means of diaries and the data obtained via the complementary method.

In this study, we measured $24 \mathrm{~h}$ excretion in both dialysate and urine, allowing us to: (1) Set up a complementary biomarker method for assessing $24 \mathrm{~h}$ intake of protein, sodium, potassium and phosphate in dialysis patients; (2) to conduct a comparison in $24 \mathrm{~h}$ intake between this method and 5-day dietary diaries and (3) to prospectively investigate the association of complementary assessment of creatinine excretion rate (CER) with mortality in dialysis patients.

\section{Materials and Methods}

\subsection{Design and Study Population}

This observational study was performed according to ethical standards laid down in the 1964 Declaration of Helsinki and its later amendments, and was approved by the Medical Ethical Committee of the University Medical Center Groningen, The Netherlands. All participating patients gave written informed consent. Inclusion criteria were twice or thrice weekly hemodialysis with $3-5 \mathrm{~h}$ per treatment, a dialysis vintage of $\geq 2$ months and absence of clinical signs of infection. 
Patients dialyzing three times per week dialyzed on either Monday-Wednesday-Friday or Tuesday-Thursday-Saturday. In both cases the mid-week dialysis session was used in this study. For patients dialyzing twice weekly, the last dialysis session of the week was used. Hypertension was defined as predialysis systolic blood pressure $>140 \mathrm{mmHg}$ and/or diastolic blood pressure $>90 \mathrm{mmHg}$ or use of antihypertensive drugs. A history of diabetes and cardiovascular disease was obtained from the patients' medical records. Cardiovascular disease was defined as a history of ischemic heart disease, congestive heart failure, coronary artery bypass grafting, percutaneous coronary intervention, stroke, or peripheral vascular disease. Blood pressure and weight were measured before and after hemodialysis. Body surface area (BSA) was calculated using the formula of Du Bois and Du Bois [23].

\subsection{Dialysis Settings}

All studies were performed with the Fresenius 5008 dialysis apparatus with a low-flux dialyzer (Fresenius Medical Care, Bad Homburg, Germany) using smartbag dialysate concentrations (Fresenius Medical Care, Bad Homburg, Germany). Blood flow and dialysate flow were between 200 and $300 \mathrm{~mL} / \mathrm{min}$ and between 500 and $700 \mathrm{~mL} / \mathrm{min}$, respectively. Dialysate temperature was 36.0 or $36.5{ }^{\circ} \mathrm{C}$. Dialysis fluid sodium varied from 136 to $140 \mathrm{mmol} / \mathrm{L}$, potassium from 1 to $3 \mathrm{mmol} / \mathrm{L}$, depending on the plasma potassium concentration, calcium from 1.25 to $1.50 \mathrm{mmol} / \mathrm{L}$ and bicarbonate from 34 to $38 \mathrm{mmol} / \mathrm{L}$.

\subsection{Sample Collection}

During the dialysis session, all dialysate was collected in a 200-liter tank. The total dialysate volume was measured by calculating the weight difference of the tank before and after the hemodialysis session. At the end of the dialysis, homogenous samples were taken from the dialysate for analysis. Venous blood was drawn directly from the dialysis line, at the start of hemodialysis and 5 min before the end of the dialysis session. Patients with significant residual diuresis, defined as a urine production of more than $200 \mathrm{~mL} / 24 \mathrm{~h}$, were asked to collect two 24-h urine collections before the hemodialysis session during which the dialysate was collected. For patients with a thrice weekly dialysis schedule this was the complete interdialytic urine production.

\subsection{Laboratory Measurements}

Sodium, potassium, urea, and total protein were measured on Roche routine chemistry analyzers (Modular P/Cobas C, Roche Diagnostics, Mannheim, Germany). Phosphate was measured using a validated ion-exchange chromatography assay with conductivity detection (Metrohm, Herisau, Switzerland). Other laboratory measurements were performed with automated and validated routine methods (Roche Diagnostics, Mannheim, Germany).

Complementary biomarker assessed (CBA) protein intake was estimated with the Maroni formula, based on a formula equivalent to the formula normally used for estimation of total protein intake based on $24 \mathrm{~h}$ urea excretion [24]:

$$
\text { CBA protein intake }(\mathrm{g} / 24 \mathrm{~h})=6.25 \times\left(0.0276 \times\left(\left(\mathrm{V}_{\text {Dialysis }} \times \mathrm{D}_{\mathrm{u}} \times n\right) / 7+\mathrm{UUE}\right)+0.031 \times \mathrm{BW}\right)+\mathrm{UPE}
$$

in which $\mathrm{V}_{\text {Dialysis }}=$ total volume of dialysate $(\mathrm{L}) ; \mathrm{D}_{\mathrm{u}}=$ measured urea concentration in the dialysate, which was collected in the tank $(\mathrm{mmol} / \mathrm{L}) ; n=$ number of dialyses per week; UUE $=24 \mathrm{~h}$ urine urea excretion $(\mathrm{mmol} / 24 \mathrm{~h})$, averaged from two $24 \mathrm{~h}$ urine collections; $\mathrm{BW}=$ body weight $(\mathrm{kg})$; and UPE $=24 \mathrm{~h}$ urine protein excretion $(\mathrm{g} / 24 \mathrm{~h})$, averaged from two $24 \mathrm{~h}$ urine collections.

Complementary biomarker assessed (CBA) sodium and potassium intake, and CBA phosphate uptake were calculated by combining dialysis and urinary excretion as follows:

$$
\text { CBA sodium intake }(\mathrm{mg} / 24 \mathrm{~h})=\left(\left(\mathrm{V}_{\text {Dialysate }} \times\left(\mathrm{D}_{\mathrm{Na}}-\mathrm{DF}_{\mathrm{Na}}\right) \times n\right) / 7+\mathrm{UNaE}\right) \times 23
$$




$$
\begin{aligned}
& \text { CBA potassium intake }(\mathrm{mg} / 24 \mathrm{~h})=\left(\left(\mathrm{V}_{\text {Dialysate }} \times\left(\mathrm{D}_{\mathrm{K}}-\mathrm{DF}_{\mathrm{K}}\right) \times n\right) / 7+\mathrm{UKE}\right) \times 39 \\
& \text { CBA phosphate uptake }(\mathrm{mg} / 24 \mathrm{~h})=\left(\left(\mathrm{V}_{\text {Dialysate }} \times \mathrm{D}_{\mathrm{PO} 4} \times n\right) / 7+\mathrm{UPO}_{4} \mathrm{E}\right) \times 95
\end{aligned}
$$

in which $\mathrm{V}_{\text {Dialysate }}=$ total volume of the spent dialysate $(\mathrm{L}) ; \mathrm{D}_{\mathrm{Na}}=$ measured sodium concentration in the collected dialysate $(\mathrm{mmol} / \mathrm{L}) ; \mathrm{DF}_{\mathrm{Na}}$ = sodium concentration in the dialysis fluid, which flows through the dialysis machine $(\mathrm{mmol} / \mathrm{L}) ; \mathrm{D}_{\mathrm{K}}=$ measured potassium concentration in the collected dialysate $(\mathrm{mmol} / \mathrm{L}) ; \mathrm{DF}_{\mathrm{K}}=$ potassium concentration in the dialysis fluid $(\mathrm{mmol} / \mathrm{L}) ; \mathrm{D}_{\mathrm{PO} 4}=$ measured phosphate concentration in the collected dialysate $(\mathrm{mmol} / \mathrm{L}) ; n=$ number of dialyses per week; $\mathrm{UNaE}=24 \mathrm{~h}$ urinary sodium excretion $(\mathrm{mmol} / 24 \mathrm{~h})$, averaged from two $24 \mathrm{~h}$ urine collections; $\mathrm{UKE}=24 \mathrm{~h}$ urinary potassium excretion $(\mathrm{mmol} / 24 \mathrm{~h})$, averaged from two $24 \mathrm{~h}$ urine collections; and $\mathrm{UPO}_{4} \mathrm{E}=24 \mathrm{~h}$ urinary phosphate excretion $(\mathrm{mmol} / 24 \mathrm{~h})$, averaged from two $24 \mathrm{~h}$ urine collections.

Creatinine excretion rate (CER) was calculated as follows:

$$
\operatorname{CER}(\mathrm{mmol} / 24 \mathrm{~h})=\left(\left(\mathrm{V}_{\text {Dialysis }} \times \mathrm{D}_{\text {Creat }} \times n\right) / 7+\mathrm{UCrE}\right)
$$

in which $\mathrm{V}_{\text {Dialysis }}=$ total volume of dialysate $(\mathrm{L}) ; \mathrm{D}_{\text {Creat }}=$ measured creatinine concentration in the collected dialysate $(\mathrm{mmol} / \mathrm{L}) ; n=$ number of dialyses per week; $\mathrm{UCrE}=24 \mathrm{~h}$ urinary creatinine excretion (mmol/24 h), averaged from two $24 \mathrm{~h}$ urine collections. To account for the difference in muscle mass due to height differences, additional analyses were employed for CER indexed to height $(\mathrm{CERH})$, calculated as follows: CER indexed to height $(\mathrm{CERH})=\mathrm{CER} /$ height $^{2}$ [25-28].

\subsection{Dietary Intake Assessment}

Participating patients were asked to record all their food and fluid intake in a dietary diary for a period of 5 days starting 5 days before the dialysis of interest. The number of servings was expressed in natural units (e.g., slice of bread or apple) or household measures (e.g., cup or spoon). The diaries were self-administered and filled out at home. Dietary data were converted into daily nutrient intakes with the use of the Dutch Food Composition Tables (Nevo 2007 and 2011), using EvryDietist calculating software. Use of phosphate binders and potassium binders were obtained from the patients' medical records.

\subsection{Statistical Analysis}

Data analysis and computations were performed with SPSS version 24 (IBM, Armonk, USA), State SE version 15 (StataCorp, Texas, USA), Analyse-IT (Analyse-it Software, Ltd., Leeds, UK) and GraphPad Prism version 5 (GraphPad software, San Diego, USA). Normally distributed data were expressed as mean \pm standard deviation (SD), and non-parametric data as median (interquartile range). Categorical variables were expressed as number (\%). Pearson correlation coefficients were used to express correlations between complementary biomarker assessed (CBA) intake and dietary assessed (DA) intake. Bland-Altman analyses were used to analyze the bias between CBA and DA intake. In Bland-Altman plots, the difference between CBA intake and DA intake ( $y$-axis) were plotted against the mean of CBA intake and DA intake ( $x$-axis), where a significant correlation indicates a proportional bias. An absence of proportional bias, but a constant difference among the methods indicates constant bias. A two-sided $p<0.05$ was considered statistical significance.

The endpoint for prospective analyses was all-cause mortality. Prospective analyses were performed using Kaplan-Meier curves and Cox regression models. Kaplan-Meier curves were made for sex stratified tertiles of CER and CERH. Cox regression analyses were employed to investigate the association of both CER and CERH with all-cause mortality, in which adjustments were made for potential confounders including age, sex, body mass index (BMI), BSA, and systolic blood pressure. Cox regression models were built in a stepwise fashion to avoid overfitting and to keep the number of predictors in proportion to the number of events. 


\section{Results}

\subsection{Patient Characteristics}

CBA and DA intakes were determined in 42 patients, $52 \%$ of which were male. Mean age at inclusion was $64( \pm 13)$ years and dialysis vintage $14(6-45)$ months. Nearly all patients (41 out of $42)$ were dialyzed thrice weekly, one patient was dialyzed twice weekly. Most patients $(n=34)$ were dialyzed $4 \mathrm{~h}$ per session, while six patients were dialyzed 3 to $3.5 \mathrm{~h}$ per session and two patients were dialyzed 4.5 to $5 \mathrm{~h}$ per session. Mean BMI and BSA were $25.6 \pm 4.3 \mathrm{~kg} / \mathrm{m}^{2}$ and $1.93 \pm 0.21 \mathrm{~m}^{2}$, respectively. Hypertension, diabetes and cardiovascular disease were prevalent in $67 \%, 29 \%$ and $43 \%$ of the patients, respectively. Half of the patients used phosphate binders (50\%). Sevelamer was used by $36 \%$ of the patients, calcium carbonate or lanthanum carbonate by $26 \%$ and calcium acetate plus magnesium carbonate (OsvaRen) by $10 \%$. Potassium binders were used in $10 \%$ of the patients (calcium polystyrene sulfonate in all). An overview of patient characteristics is shown in Table 1.

Table 1. Patient characteristics.

\begin{tabular}{|c|c|c|}
\hline Baseline Characteristics & Average/Number & Range \\
\hline \multicolumn{3}{|l|}{ Demographics } \\
\hline Age, years & $64 \pm 13$ & $25-86$ \\
\hline Gender, $n$ male $(\%)$ & $22(52)$ & \\
\hline Race, $n$ Caucasian $(\%)$ & $39(93)$ & \\
\hline \multicolumn{3}{|l|}{ Dialysis-related } \\
\hline \multicolumn{3}{|l|}{ Dialysis sessions, $\mathrm{n}(\%)$} \\
\hline 2 sessions per week & $1(2)$ & \\
\hline 3 sessions per week & $41(98)$ & \\
\hline \multicolumn{3}{|l|}{ Hours per dialysis, $\mathrm{n}(\%)$} \\
\hline 3 to $3.5 \mathrm{~h}$ & $6(14)$ & \\
\hline $4 \mathrm{~h}$ & $34(81)$ & \\
\hline 4.5 to $5 \mathrm{~h}$ & $2(5)$ & \\
\hline Residual diuresis, $n(\%)$ & $22(52)$ & \\
\hline Urinary volume, L & $0.84 \pm 0.57$ & $0.14-2.39$ \\
\hline Dialysis vintage, months & $14(6-45)$ & $2-202$ \\
\hline Ultrafiltration volume, $\mathrm{ml}$ & $1926 \pm 921$ & $1425-2725$ \\
\hline \multicolumn{3}{|l|}{ Body composition } \\
\hline Target body weight, kg & $80.2 \pm 15.6$ & $72.5-89.9$ \\
\hline Interdialytic weight gain, $\mathrm{kg}$ & $1.17 \pm 1.12$ & $-1.7-4.4$ \\
\hline Height, m & $1.75 \pm 0.09$ & $1.66-1.83$ \\
\hline BMI, $\mathrm{kg} / \mathrm{m}^{2}$ & $25.6 \pm 4.3$ & $22.7-28.8$ \\
\hline $\mathrm{BSA}, \mathrm{m}^{2}$ & $1.93 \pm 0.21$ & $1.82-2.06$ \\
\hline \multicolumn{3}{|l|}{ Pre-existing disease } \\
\hline Hypertension, $n(\%)$ & $28(67)$ & \\
\hline Diabetes, $n(\%)$ & $12(29)$ & \\
\hline Cardiovascular disease, $n(\%)$ & $18(43)$ & \\
\hline \multicolumn{3}{|l|}{ Medication usage } \\
\hline Use of phosphate binders, $n(\%)$ & $21(50)$ & \\
\hline Sevelamer & $15(36)$ & \\
\hline Calciumcarbonate or lanthanumcarbonate & $11(26)$ & \\
\hline Calciumacetate and magnesiumcarbonate (OsvaRen) & $6(14)$ & \\
\hline Use of potassium binders, $n(\%) *$ & $4(10)$ & \\
\hline
\end{tabular}

\subsection{Clinical and Laboratory Parameters Before and After Dialysis}

During dialysis, mean body weight declined from $80.0 \pm 16.0 \mathrm{~kg}$ before dialysis to $78.7 \pm 16.0$ $\mathrm{kg}$ after dialysis $(p<0.001)$, with a mean ultrafiltration volume of $1926 \pm 921 \mathrm{~mL}$. Systolic, but not diastolic blood pressure, declined significantly from $147 \pm 21 \mathrm{mmHg}$ to $138 \pm 27 \mathrm{mmHg}(p=0.012)$. 
Plasma potassium $(4.9 \pm 0.5 \mathrm{vs} 3.5 \pm 0.4 \mathrm{mmol} / \mathrm{L} ; p<0.001)$, phosphate $(1.6 \pm 0.6 \mathrm{vs} .0 .8 \pm 0.2 \mathrm{mmol} / \mathrm{L}$; $p<0.001)$, urea (20 \pm 5 vs. $6 \pm 2 \mathrm{mmol} / \mathrm{L} ; p<0.001)$ and creatinine (707 $\pm 196 \mathrm{vs} .265 \pm 94 \mu \mathrm{mol} / \mathrm{L}$; $p<0.001$ ) all declined during dialysis. Conversely, hemoglobin increased during dialysis (from $6.9 \pm 0.7$ to $7.4 \pm 1.0 \mathrm{mmol} / \mathrm{L} ; p<0.001$ ). The same was true for hematocrit (from $0.34 \pm 0.04$ to $0.36 \pm 0.04 \%$; $p<0.001$ ) and plasma albumin (from $40 \pm 5$ to $43 \pm 4 \mathrm{~g} / \mathrm{L} ; p<0.001$ ). An overview of clinical and laboratory parameters before and after dialysis is shown in Table 2.

Table 2. Clinical and laboratory parameters before and after dialysis.

\begin{tabular}{cccc}
\hline Variable & Before Dialysis & After Dialysis & $p$-Value \\
\hline Clinical & & & \\
Systolic blood pressure (mmHg) & $147 \pm 21$ & $138 \pm 27$ & 0.012 \\
Diastolic blood pressure, (mmHg) & $69 \pm 12$ & $67 \pm 11$ & 0.163 \\
Pulse, min $^{-1}$ & $74 \pm 14$ & $73 \pm 12$ & 0.631 \\
Body weight, $\mathrm{kg}$ & $80.0 \pm 16.0$ & $78.7 \pm 16.0$ & $<0.001$ \\
Laboratory & & & \\
Hemoglobin (mmol/L) & $6.9 \pm 0.7$ & $7.4 \pm 1.0$ & 0.001 \\
Hematocrit & $0.34 \pm 0.04$ & $0.36 \pm 0.04$ & 0.012 \\
Sodium $(\mathrm{mmol} / \mathrm{L})$ & $138 \pm 3$ & $139 \pm 2$ & 0.023 \\
Potassium $(\mathrm{mmol} / \mathrm{L})$ & $4.9 \pm 0.5$ & $3.5 \pm 0.4$ & $<0.001$ \\
Phosphate $(\mathrm{mmol} / \mathrm{L})$ & $1.6 \pm 0.6$ & $0.8 \pm 0.2$ & $<0.001$ \\
Albumin $(\mathrm{g} / \mathrm{L})$ & $40 \pm 5$ & $43 \pm 4$ & $<0.001$ \\
Urea $(\mathrm{mmol} / \mathrm{L})$ & $20 \pm 5$ & $6 \pm 2$ & $<0.001$ \\
Creatinine $(\mu \mathrm{mol} / \mathrm{L})$ & $707 \pm 196$ & $265 \pm 94$ & $<0.001$ \\
\hline
\end{tabular}

\subsection{Comparison of CBA Intake with DA Intake}

Mean CBA protein intake was significantly lower than DA protein intake (63 \pm 19 vs. $71 \pm 19 \mathrm{~g} / 24 \mathrm{~h} ; p=0.003)$. Mean CBA sodium intake was significantly higher than DA sodium intake ( $4035 \pm 2316$ vs. $2123 \pm 616 \mathrm{mg} / 24 \mathrm{~h} ; p<0.001)$. Mean CBA potassium intake was significantly lower than DA potassium intake (2014 \pm 907 vs. $2445 \pm 568 \mathrm{mg} / 24 \mathrm{~h} ; p=0.008)$. Mean CBA phosphate uptake was significantly higher than DA phosphate intake (1427 \pm 637 vs. $1221 \pm 276 \mathrm{mg} / 24 \mathrm{~h}$; $p=0.029$ ). An overview of CBA intakes and DA intakes is shown in Table 3. CBA intake is plotted against DA intake for protein (Figure 1a), sodium (Figure 2a), potassium (Figure 3a) and phosphate (Figure 4a).

Table 3. Mean values of complementary biomarker assessed (CBA) intakes and dietary assessed (DA) intakes of protein, sodium, potassium and phosphate.

\begin{tabular}{cccc}
\hline Variable & CBA Intake * & DA Intake & $p$-Value \\
\hline Protein $(\mathrm{g} / 24 \mathrm{~h})$ & $63 \pm 19$ & $71 \pm 19$ & 0.003 \\
Sodium $(\mathrm{mg} / 24 \mathrm{~h})$ & $4035 \pm 2316$ & $2123 \pm 616$ & $<0.001$ \\
Potassium $(\mathrm{mg} / 24 \mathrm{~h})$ & $2041 \pm 907$ & $2445 \pm 568$ & 0.008 \\
Phosphate $(\mathrm{mg} / 24 \mathrm{~h})$ & $1427 \pm 637$ & $1221 \pm 276$ & 0.029 \\
\hline
\end{tabular}

* = uptake in the case of phosphate. 


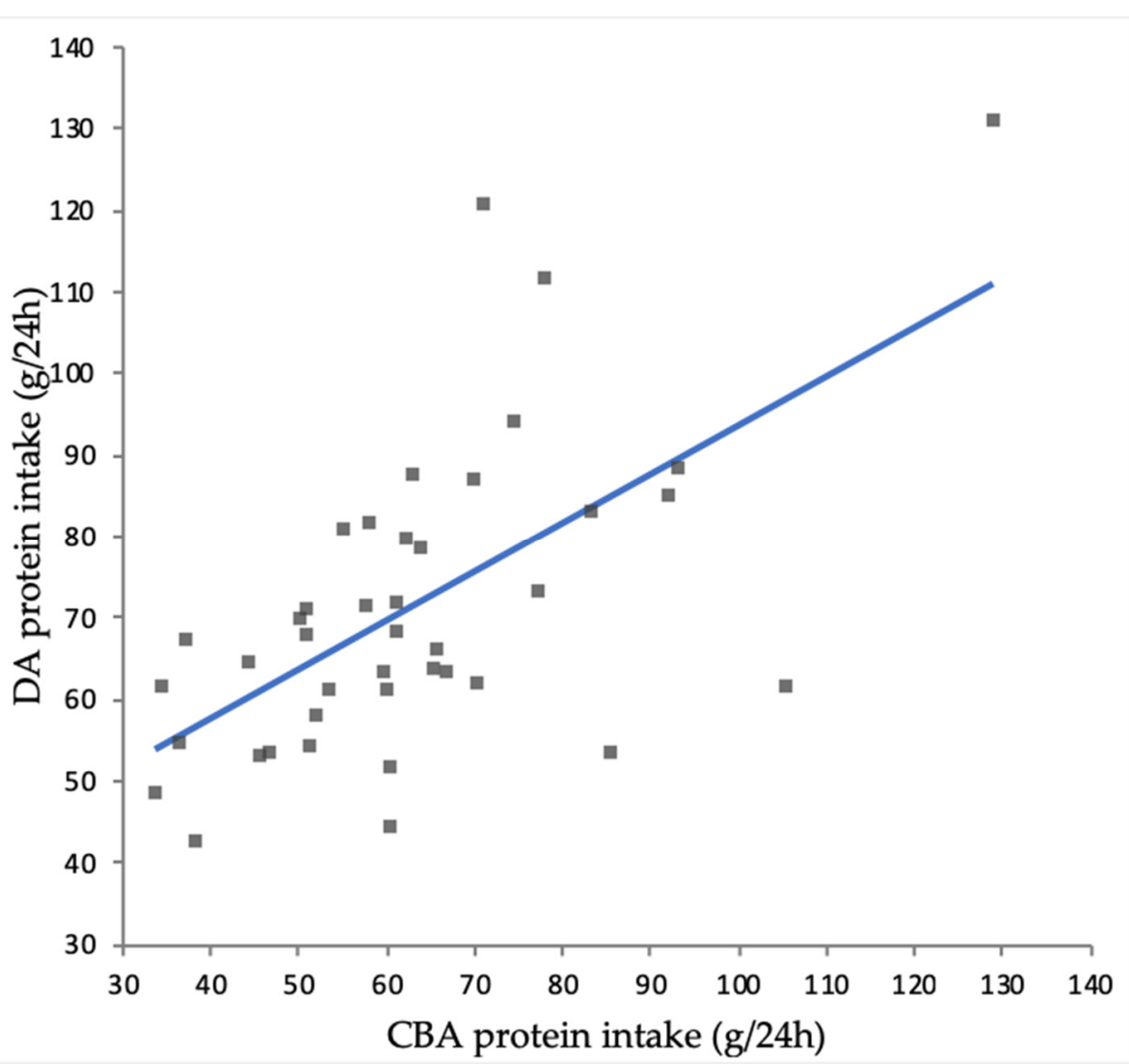

(a)

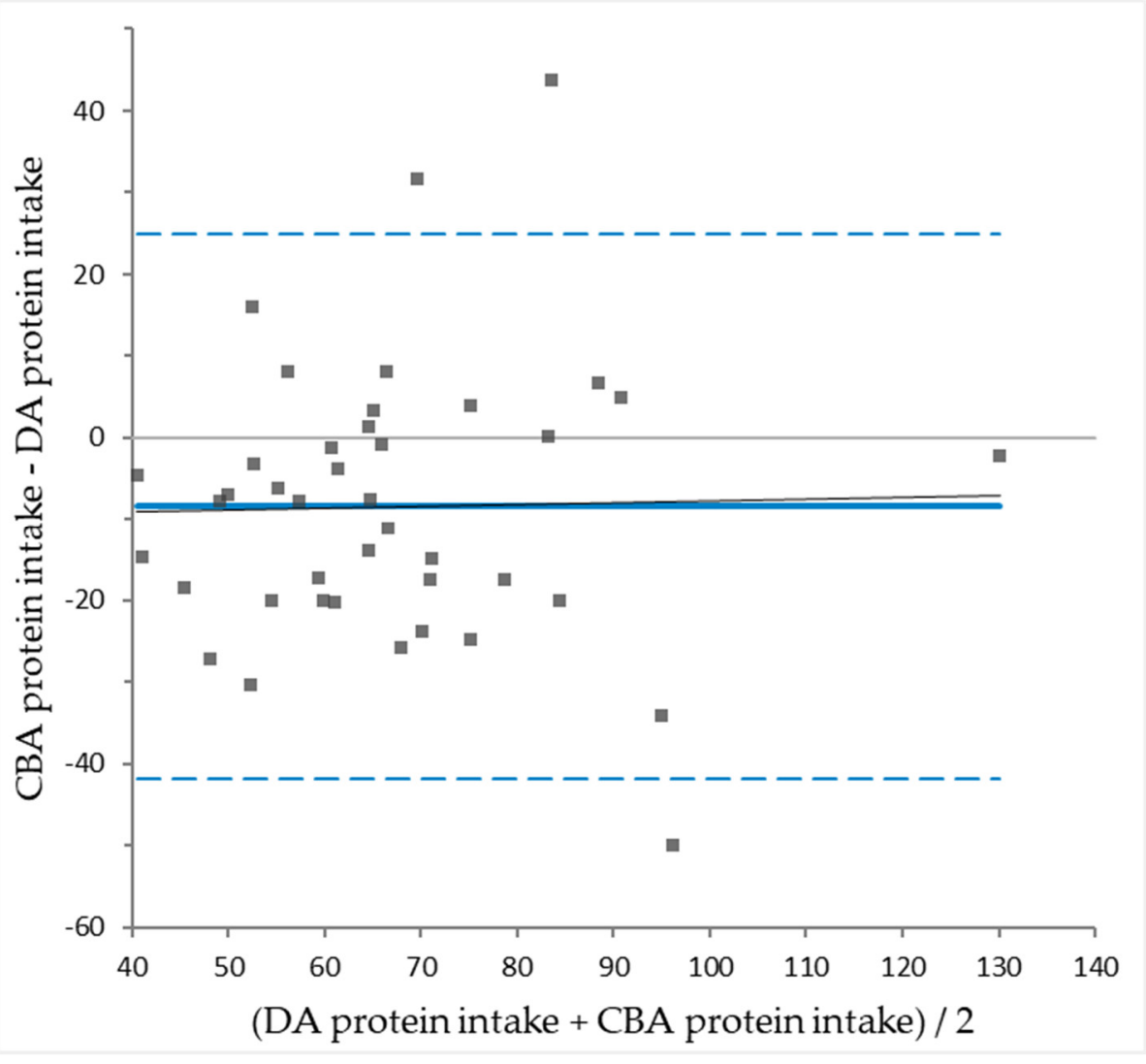

(b)

Figure 1. (a) Comparison of complementary biomarker assessed (CBA) protein intake and diary assessed (DA) protein intake $(r=0.610 ; p<0.001)$; (b) Bland-Altman plot for CBA protein intake and DA protein intake, showing constant bias $(p=0.003)$, and no proportional bias $(r=-0.023 ; p=0.888)$. 


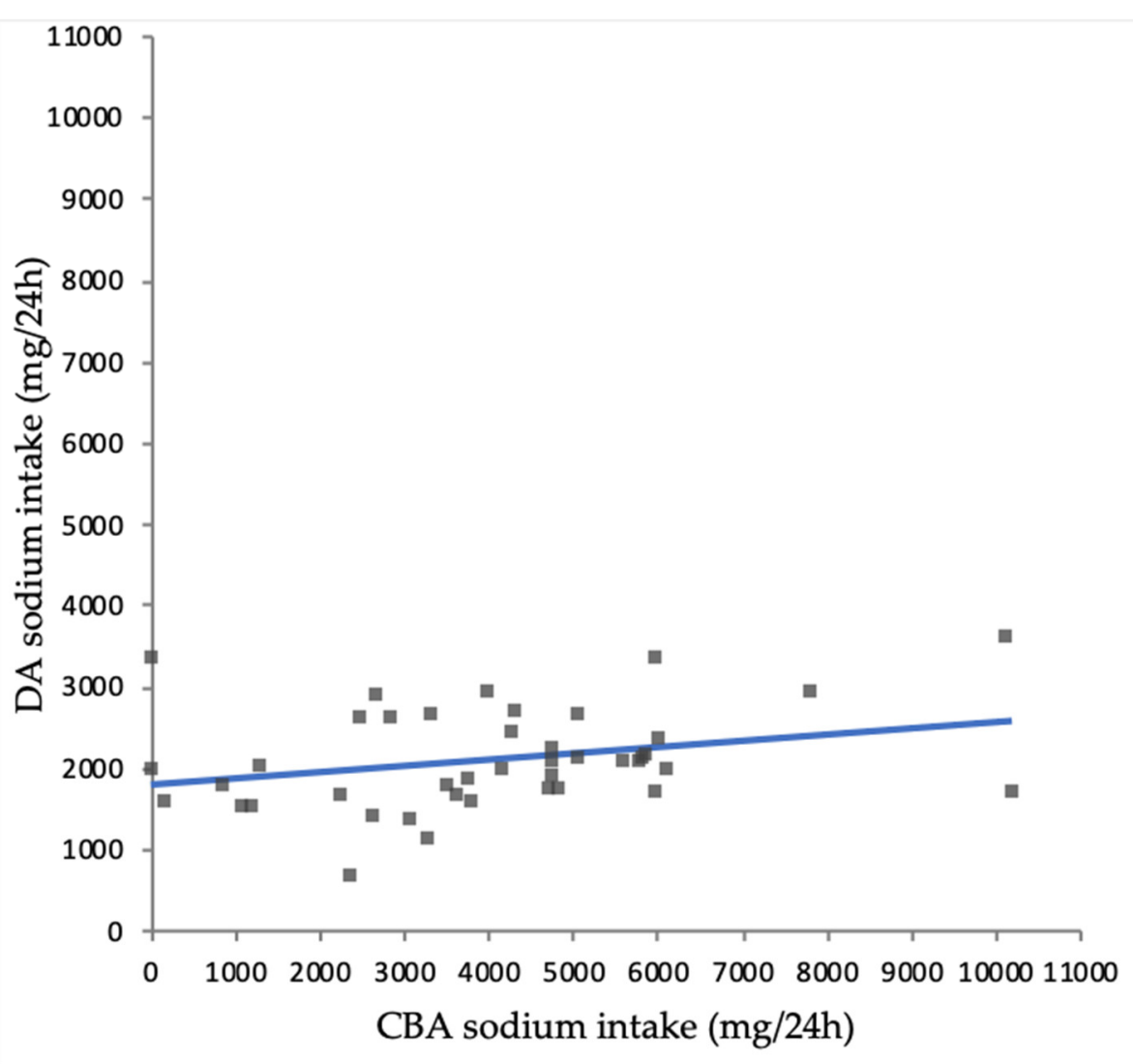

(a)

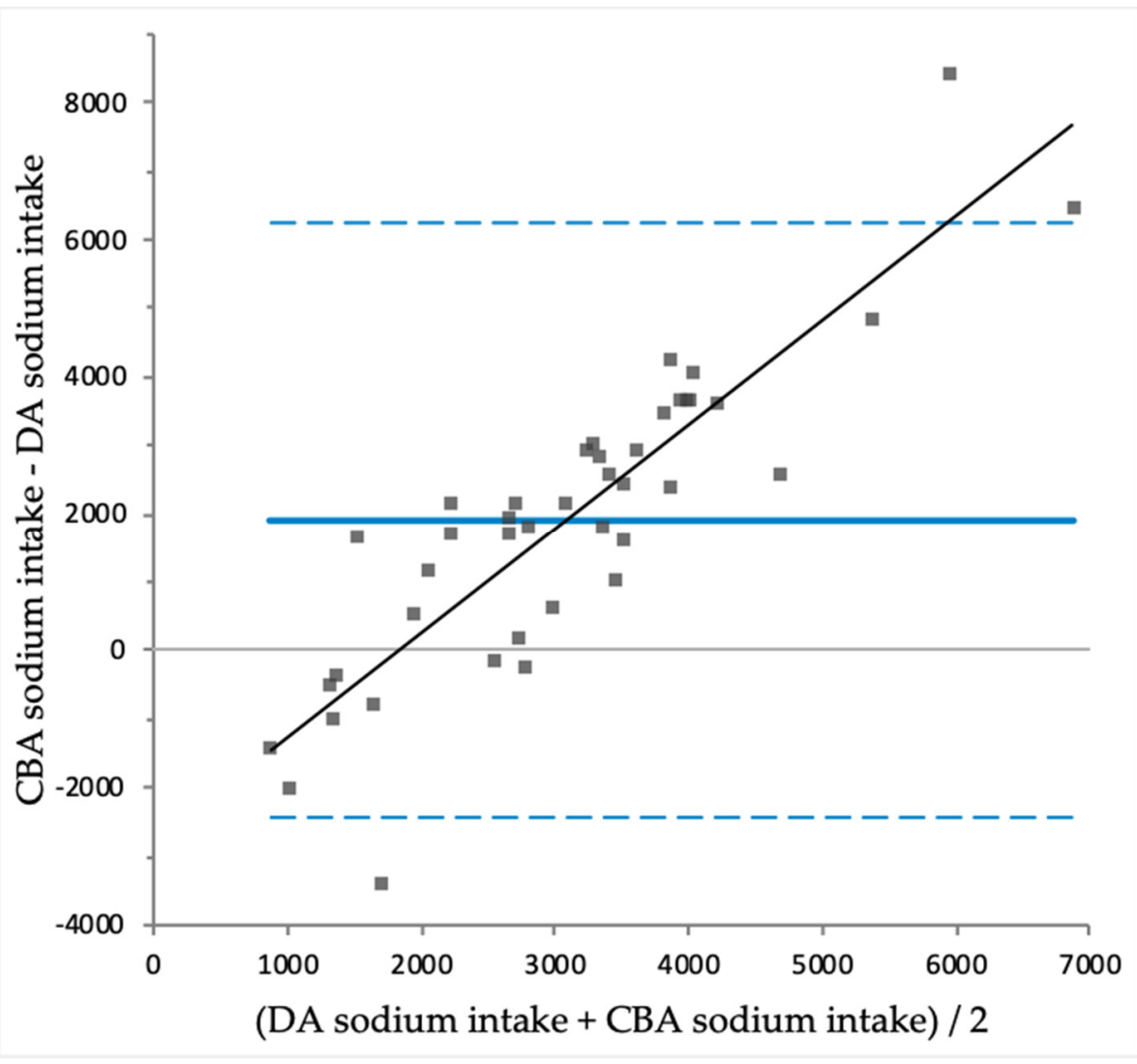

(b)

Figure 2. (a) Comparison of complementary biomarker assessed (CBA) sodium intake and diary assessed (DA) sodium intake ( $r=0.297 ; p=0.056)$; (b) Bland-Altman plot for CBA sodium intake and DA sodium intake, with significant proportional bias $(r=0.887 ; p<0.001)$. 


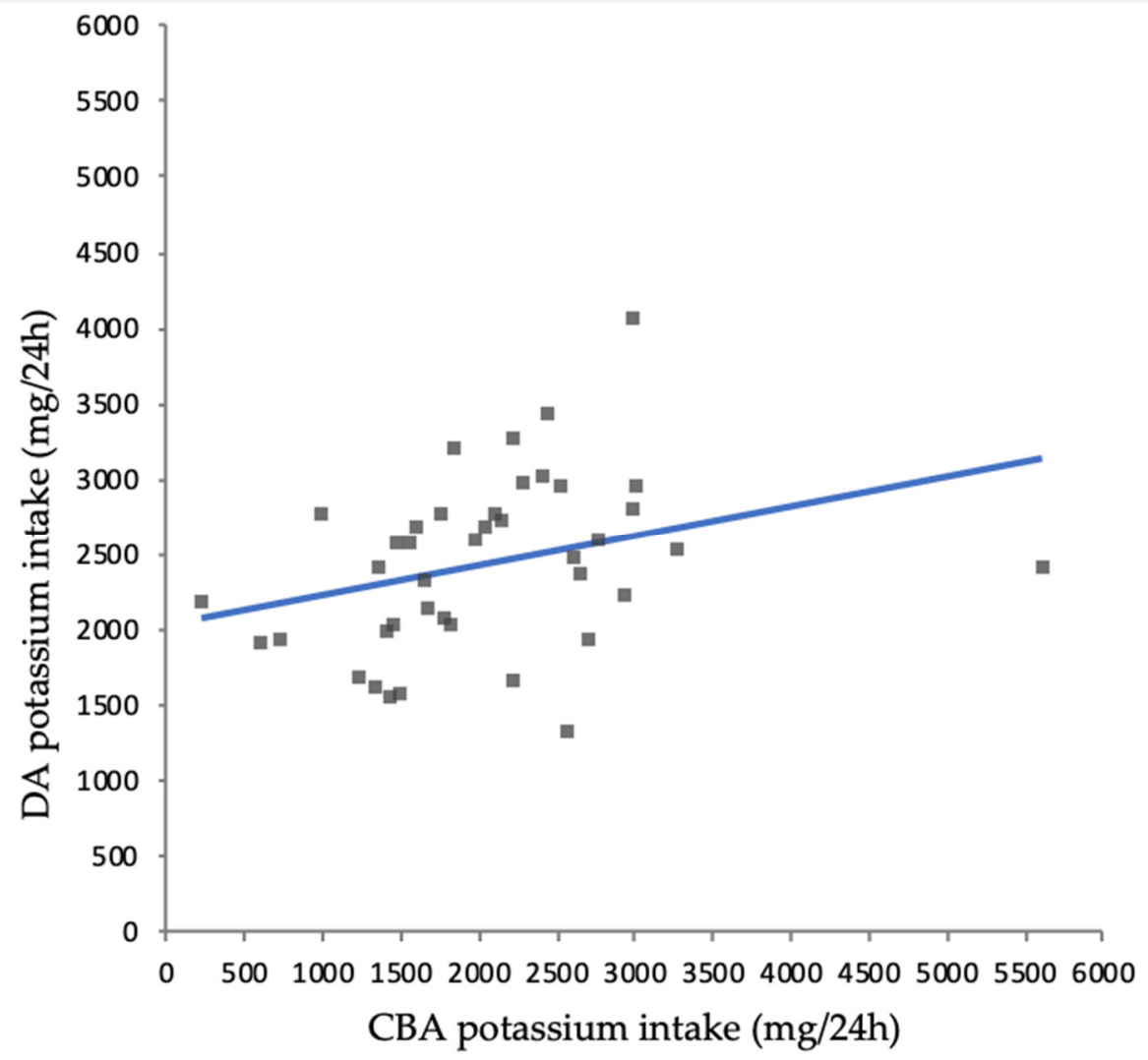

(a)

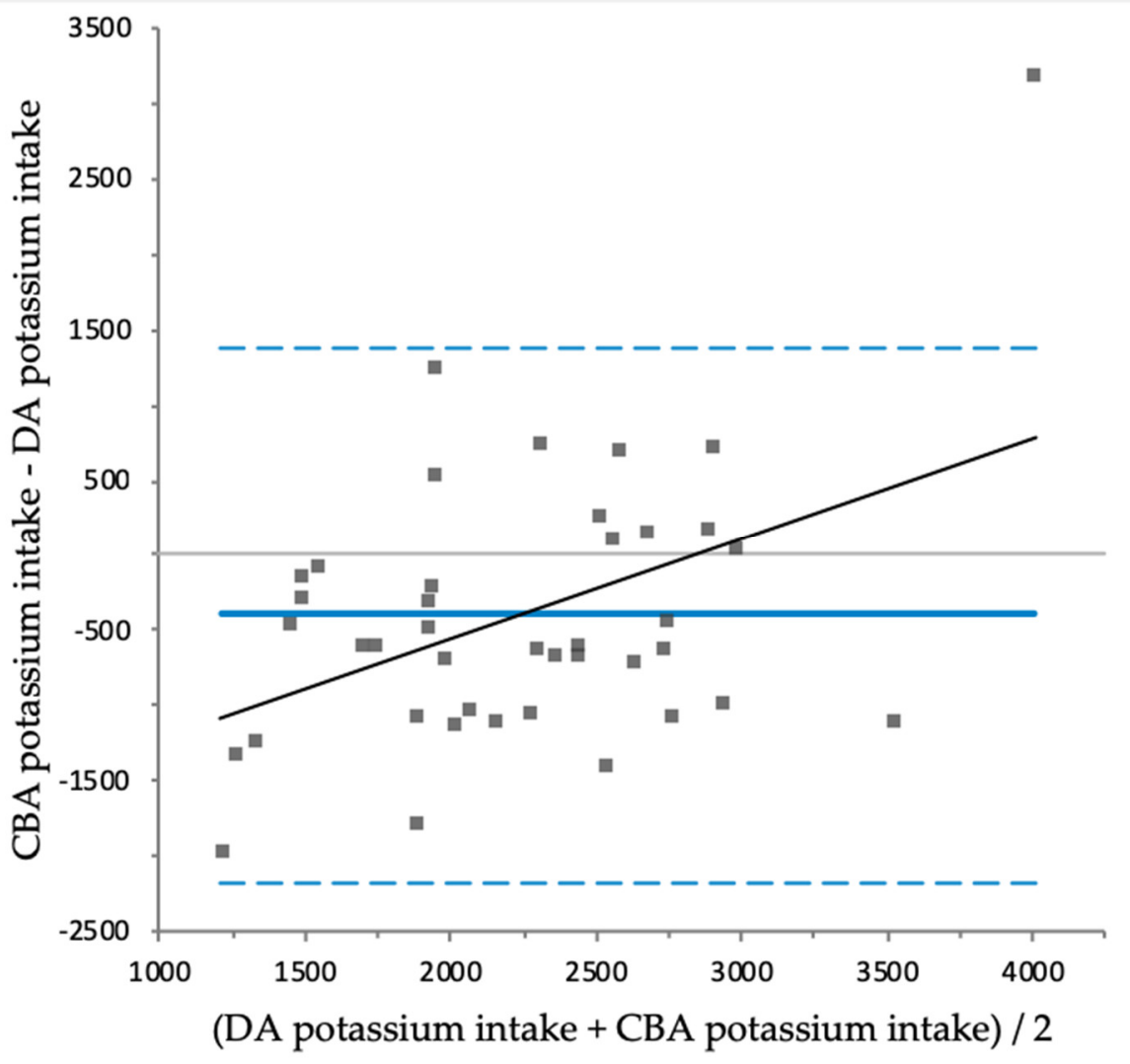

(b)

Figure 3. (a) Comparison of complementary biomarker assessed (CBA) potassium intake and diary assessed (DA) potassium intake $(r=0.312 ; p=0.047)$; (b) Bland-Altman plot for CBA potassium intake and DA potassium intake, with significant proportional bias $(r=0.446 ; p=0.003)$. 


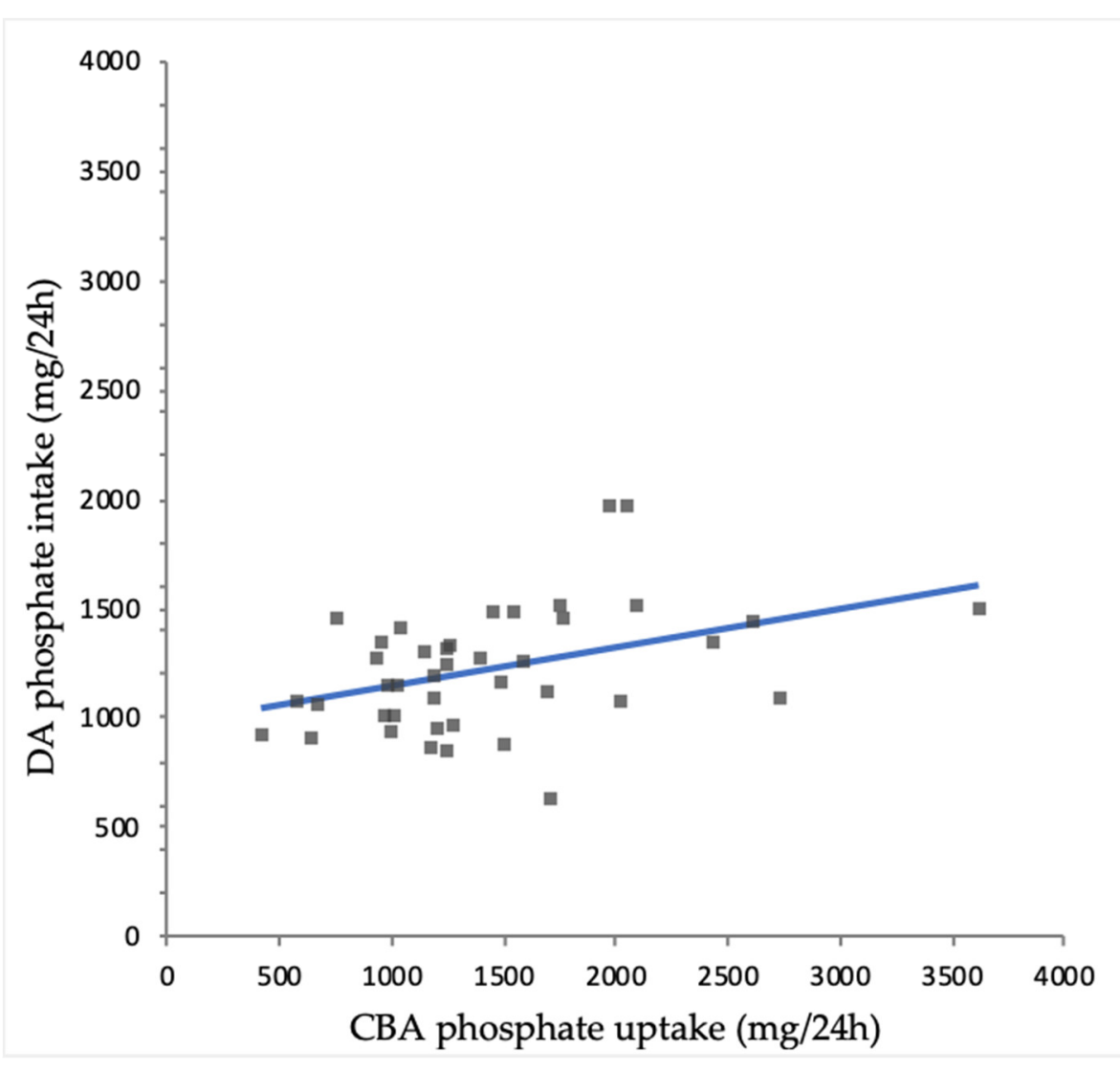

(a)

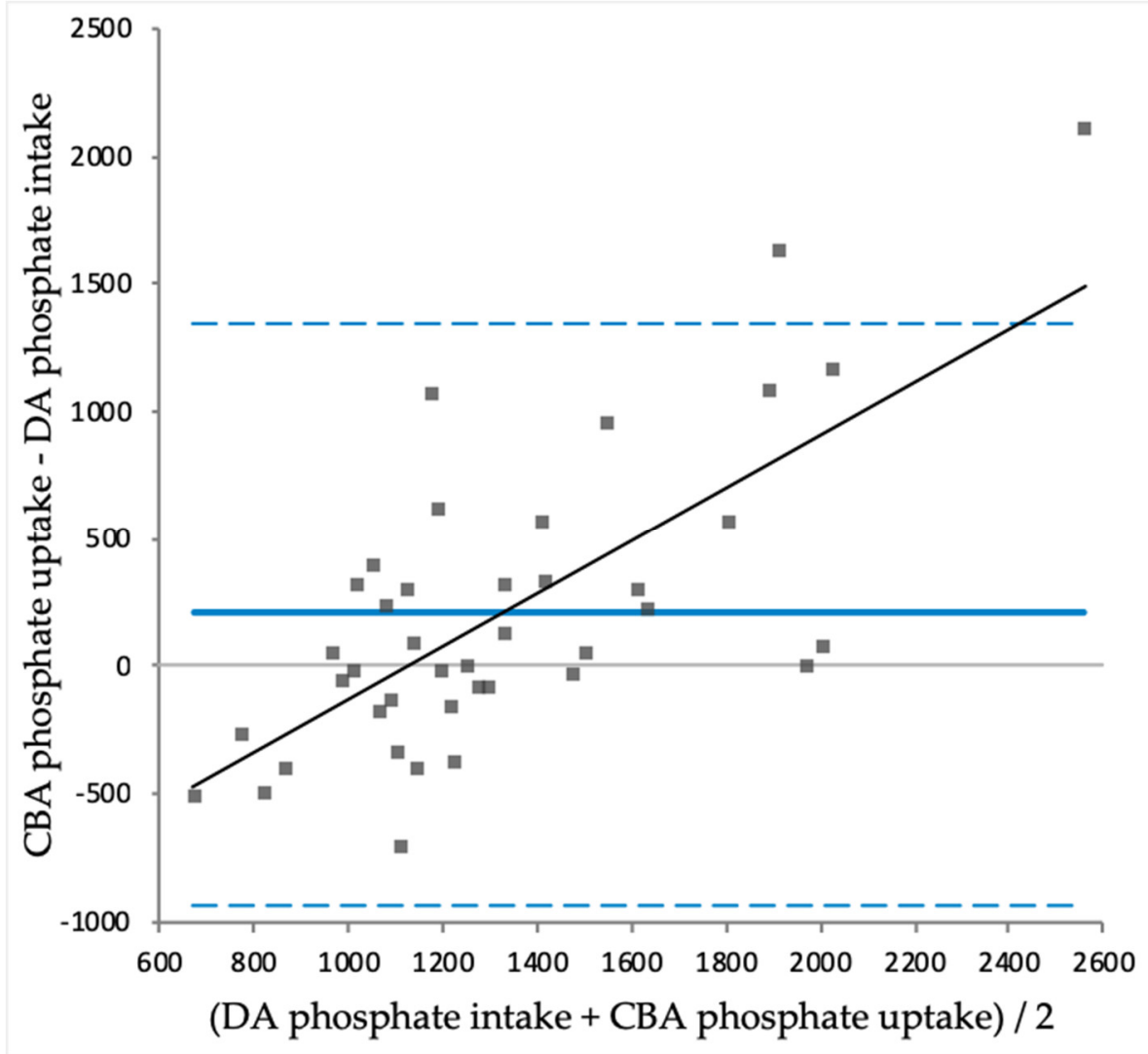

(b)

Figure 4. (a) Comparison of complementary biomarker assessed (UBA) phosphate uptake and diary assessed (DA) phosphate intake $(r=0.409 ; \quad p=0.008)$; (b) Bland-Altman plot for CBA phosphate uptake and DA phosphate intake, with significant proportional bias $(r=0.710 ; p<0.001)$. 
CBA protein correlated significantly with DA protein intake $(r=0.610 ; p<0.001)$, while CBA sodium intake did not correlate significantly with DA sodium intake $(r=0.297 ; p=0.056)$. CBA potassium intake correlated significantly with DA potassium intake $(r=0.312 ; p=0.047)$ and CBA phosphate uptake correlated significantly with DA phosphate intake $(r=0.409 ; p=0.008)$.

The differences between CBA intakes and DA intakes are plotted against the mean of CBA intakes and DA intakes for protein (Figure 1b), sodium (Figure 2b), potassium (Figure 3b) and phosphate (Figure $4 \mathrm{~b})$. For protein intake, Bland-Altman analysis showed no proportional bias $(r=-0.023$; $p=0.888$ ). However, compared to CBA protein intake, mean DA protein intake was $13 \%$ higher and in 30 out of $41(73 \%)$ patients DA protein intake overestimated CBA protein intake, consistent with significant constant bias $(p=0.003)$.

For sodium, potassium and phosphate, Bland-Altman analysis showed proportional bias, as there were significant correlations found between the difference of CBA intakes and DA intakes and the mean of CBA intakes and DA intakes of sodium $(r=0.887 ; p<0.001)$, potassium $(r=0.446 ; p=0.003)$ and phosphate $(r=0.710 ; p<0.001)$. These results indicate that compared to CBA intakes, DA intakes overestimate sodium and potassium intake in the lower end of the intake spectrum, while DA intakes underestimate intakes in the higher end of the intake spectrum. Similarly, compared to CBA phosphate uptake, DA phosphate intake is higher in the lower end of the spectrum, but lower in the higher end of the spectrum of intake and uptake. The differences between methods were largest at the extremes of intake. Exclusion of the four patients who used potassium binders did not have a substantial effect on the correlations for potassium (data not shown).

\subsection{Prospective Analysis}

CER and survival data were available for 40 dialysis patients. Mean CER was $8.7 \pm 3.3 \mathrm{mmol} / 24 \mathrm{~h}$ and mean CERH was $2.8 \pm 1.0 \mathrm{mmol} / 24 \mathrm{~h} / \mathrm{m}^{2}$. Median follow-up from baseline was $26.6(25.3-31.5)$ months. During this prospective follow-up, nine dialysis patients (23\%) died. Patients who died had significantly lower CER $(5.8 \pm 2.0$ vs. $9.6 \pm 3.1 \mathrm{mmol} / 24 \mathrm{~h} ; p=0.001)$ and CERH $(1.8 \pm 0.5$ vs. $\left.3.1 \pm 0.9 \mathrm{mmol} / 24 \mathrm{~h} / \mathrm{m}^{2} ; p<0.001\right)$ than dialysis patients who survived during follow-up. According to sex-stratified tertiles of CER, the incidence of mortality during follow-up was 8 of 13 (62\%) for the lowest tertile, whereas it was 1 of $14(7 \%)$ and 0 of $13(0 \%)$ for the middle and highest CER tertile, respectively (log-rank test $p<0.001$ ). Using sex-stratified tertiles of CERH yielded similar results. Kaplan-Meier curves for CER and CERH are shown in Figure 5. Results of Cox regression analyses for mortality are shown in Table 4. CER and CERH were significantly associated with mortality, with hazard ratios of $0.59(0.42-0.84)(p=0.003)$ and $0.13(0.04-0.45)(p=0.001)$, respectively. These associations remained consistently present, independent of adjustment for potential confounders including age, sex (model 2), BMI (model 3), BSA (model 4) and blood pressure (model 5).

Table 4. Cox regression analyses for prediction of patient mortality based on excretion of creatinine excretion rate (CER) and creatinine excretion indexed to height ${ }^{2}(\mathrm{CERH})$.

\begin{tabular}{ccccc}
\hline \multirow{2}{*}{ Model } & \multicolumn{2}{c}{ CER } & \multicolumn{2}{c}{ CERH } \\
\cline { 2 - 5 } & HR (95\% CI) & $p$-Value & HR (95\% CI) & $p$-Value \\
\hline 1 & $0.59(0.42-0.84)$ & 0.003 & $0.13(0.04-0.45)$ & 0.001 \\
2 & $0.50(0.29-0.83)$ & 0.007 & $0.14(0.03-0.61)$ & 0.009 \\
3 & $0.47(0.28-0.79)$ & 0.005 & $0.12(0.03-0.56)$ & 0.007 \\
4 & $0.49(0.29-0.82)$ & 0.007 & $0.14(0.03-0.62)$ & 0.010 \\
5 & $0.50(0.30-0.82)$ & 0.007 & $0.14(0.03-0.61)$ & 0.009 \\
\hline
\end{tabular}

Model 1, crude model; model 2, adjusted for age and sex; model 3, as model 2, additionally adjusted BMI; model 4, as model 2, additionally adjusted for BSA; model 5, as model 2, additionally adjusted for systolic blood pressure. 
CER

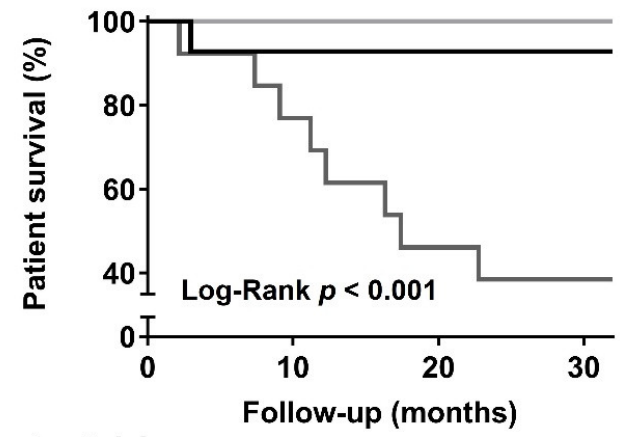

Subjects at risk

$\begin{array}{rrrll}- \text { Tertile 1 } & 13 & 10 & 6 & 2 \\ - \text { Tertile 2 } & 14 & 13 & 13 & 6 \\ - \text { Tertile 3 } & 13 & 13 & 13 & 8\end{array}$

(a)
CERH

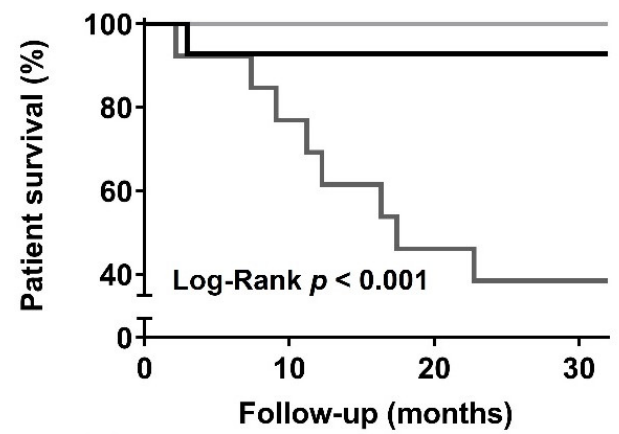

Subjects at risk

$\begin{array}{rrrll}- \text { Tertile 1 } & 13 & 10 & 6 & 3 \\ - \text { Tertile 2 } & 14 & 13 & 13 & 5 \\ - \text { Tertile 3 } & 13 & 13 & 13 & 8\end{array}$

(b)

Figure 5. (a) Kaplan-Meier curves for sex-stratified tertiles of creatinine excretion rate (CER) and (b) creatinine excretion rate, indexed to height ${ }^{2}$ (CERH).

\section{Discussion}

To the best of our knowledge, this study is the first to use urinary and dialysate collections to set up a complementary biomarker method for assessing daily intake of protein, sodium, potassium and intestinal absorption of phosphate in dialysis patients, and to compare this method with dietary intake assessed by 5-day dietary diaries. Analysis of bias showed a constant bias for protein intake, where diaries overestimated protein intake. Compared to CBA intake, mean DA intake was lower for sodium, but higher for potassium. Mean CBA uptake of phosphate was higher than DA phosphate intake. For sodium, potassium and phosphate, significant proportional bias was found. Diaries seemed to overestimate intake in the lower end of the intakes, while underestimating intake in the higher end of intakes, most notably for sodium. Survival analyses showed that CER was a significant predictor of all-cause mortality, with low CER associated with worse survival.

Diet is a major lifestyle-related risk factor of a wide range of chronic diseases. Contrary to other lifestyle risk factors, dietary intake is more difficult to measure, and inaccurate dietary assessment may be a serious obstacle to understanding the impact of dietary factors on disease. Dietary intake can be assessed through several methods of self-reported dietary intakes, all of which are prone to many potential biases and errors $[8,10]$. To overcome these potential errors, and the additional bias introduced by the use of food composition tables, recovery biomarkers are often recommended and used to validate self-reported intakes $[10,15,29]$. To adjust for the removal of solutes by dialysis, we have complemented urinary excretion with dialysis excretion to set up an applicable biomarker method.

Protein energy malnutrition is used to describe a state of decreased body stores of protein and energy fuels (body protein and fat masses) and is also known as protein energy wasting or uremic malnutrition [1]. PEM is a major threat for patients on dialysis, as it is the strongest risk factor for morbidity and mortality in dialysis patients [2]. The precise mechanisms of PEM remain to be elucidated, but the common pathway of potential causes is a state of increased protein degradation and decreased protein synthesis $[1,30]$. Therefore, the mainstay of preventing PEM is provision of an adequate protein supply. Current Kidney Dialysis Outcome Quality Initiative (KDOQI) guidelines suggest a protein intake of approximately 1.2 grams of protein per kilogram of body weight per day for patients on dialysis [1,31]. A large study (HEMO-study) in 1901 hemodialysis patients used self-reported intake to assess dietary protein intake and showed that these targets were not met [32]. In our study, the KDOQI guidelines would translate to a mean intake of $96 \mathrm{~g} / 24 \mathrm{~h}$, which was not 
met by either method of assessment. In addition, in most patients, dietary diaries overestimated protein intake, and mean protein intake by dietary diaries was 13\% higher than the excretion method. These findings implicate that the true intake of protein in dialysis patients may be lower than the protein intakes found in studies using self-reported intakes, e.g., the HEMO study [32], which may contribute to the high prevalence of PEM in dialysis patients. Diagnostic criteria of PEM can be classified into four categories, biochemistry, body mass, muscle mass and protein intake. In this study, we investigated the potential of muscle mass, as a tool for monitoring protein energy malnutrition in dialysis. Creatinine excretion via $24 \mathrm{~h}$ urine collection is considered a reliable method for the assessment of muscle mass in subjects not dependent on dialysis, and in these subjects, low creatinine excretion has been shown to be a very strong predictor of poor long-term outcome [17-22]. Similarly, we found a strong association between CER and mortality in this study, despite the low number of participants. CER may therefore serve as a tool for monitoring protein energy malnutrition in dialysis.

It is important to note that increasing protein intake to prevent PEM also increases the intake of potentially harmful elements, such as sodium, potassium and phosphate. It is therefore also necessary to be able to accurately assess these nutrients. Dialysis patients are given restrictions on sodium intake, as excessive sodium can contribute to hypertension and volume overload, the latter of which can even contribute to PEM [1]. Normally, over $90 \%$ of dietary sodium is excreted renally and recovered in urine [33]. Studies comparing dietary records with urinary sodium excretion have found a wide variety of correlation coefficients, ranging from 0.11 among postmenopausal Chinese women with prehypertension to 0.42 in the INTERMAP study, comprising 4680 participants [34-36]. Our results lie somewhat in the middle between these, with a correlation of 0.30 between dietary diaries and excretion. Compared to CBA sodium intake, DA sodium intake was nearly $50 \%$ lower, even lower if the excretion method was adjusted for a $10 \%$ loss of sodium in sweat and feces. Possible reasons for the differences might be underreporting of sodium intake in diaries or the omission to report added salt during cooking or at the table. In addition, we found strong proportional bias among the methods. Compared to the biomarker method, dietary diaries overestimate sodium intake in the lower end of the intake spectrum, while underestimating in the higher end of the intake spectrum. These data fit the possibility of participants giving socially desirable answers, i.e., overreporting when consuming too little and, more relevant, underreporting when consuming too much sodium. Sodium assessment in dialysis patients may therefore be unreliable when using dietary diaries.

In contrast with the mean underestimation of sodium intake using urinary sodium collection, dietary diaries of potassium intake often exceeded those of urinary collection, which was also seen in our mean data. This is partially because $15-20 \%$ of potassium is lost in the feces and another portion is excreted from sweat [37]. Studies comparing dietary diaries with $24 \mathrm{~h}$ urinary potassium excretion found a wide range of correlations, varying from 0.23 in 200 adolescents to 0.35 in 149 healthy volunteers [38,39]. Here, a comparable correlation of 0.31 was found between CBA and DA potassium intake. Proportional bias was also found for potassium, though less pronounced.

Dietary advices for dialysis patients are focused on limiting phosphate intake to prevent hyperphosphatemia as hyperphosphatemia is central to the development and progression of CKD-mineral bone disorder, which is associated with higher fracture, cardiovascular, and mortality risk $[40,41]$. Under steady state conditions, whole balance phosphate is maintained by adjusting urinary retention of phosphate to match absorbed phosphate from the diet [42]. Therefore, $24 \mathrm{~h}$ measurements of urinary phosphate have been considered a reliable biomarker for dietary phosphate absorption. Several studies have confirmed this in patients with preserved kidney function $[16,43,44]$. In our study we compared CBA phosphate uptake with DA phosphate intake and found that on average CBA phosphate uptake was higher. Since the amount of phosphate that is not absorbed, for instance due to phosphate binders, does not contribute to hyperphosphatemia, phosphate excretion may be a more useful tool to monitor the phosphate load in dialysis patients. Additional reasons that DA phosphate intake may be unreliable is the dependence on nutrient databases, which are often 
inaccurate or incomplete for phosphate. Direct chemical analysis of foods showed that databases can drastically underestimate phosphate content, up to 70\% [45-49].

The strength of this study is that we collected the total dialysate instead of taking several samples during the dialysis sessions, thereby increasing the accuracy of the dialysate excretion measurements. Also, dietary diaries were recorded for 5 days, decreasing the possible bias due to day-to-day variability in food intake. However, there are also some limitations, for instance the relatively small sample size of the study. A second limitation is that CER was only measured at one point in time, while multiple measurements could have allowed us to calculate CER change over time, which could be more reliable. It should also be noted that we presented CER as a tool for monitoring PEM, but diagnosis and follow-up of PEM should be based on multiple assessment tools, preferably in at least three out of the four earlier mentioned categories, biochemistry, body mass, muscle mass, and protein intake [1]. In addition, we did not assess muscle mass by other methods, including magnetic resonance imaging, computed tomography, dual-energy $X$-ray absorptiometry and bioelectric impedance analysis [50], which precluded us from comparing the present method with these techniques. Furthermore, because our participants were Caucasian, our results cannot be extrapolated to other ethnic groups. Most importantly, we have assumed that our excretion method for dialysis patients is the equivalent of $24 \mathrm{~h}$ urinary excretion in a non-dialyzing setting. While this is theoretically the case, it is still necessary to first assess its validity, reproducibility, and ability to assess the variation between different dialysis sessions.

\section{Conclusions}

In conclusion, combined urinary and dialysate collection have been used to set up an unbiased biomarker method for assessing the dietary intake of protein, sodium, potassium and phosphate. We have shown that even if nutritional intake is assessed optimally from the perspective of diaries, e.g., 5-day dietary diaries, there are significant differences and bias between the data obtained by means of the biomarker method and the data obtained by dietary diaries. A significant correlation was found between the methods for assessing protein intake, however, dietary diaries overestimated protein intake in most patients. These findings implicate that the true intake of protein in dialysis patients may be lower than the protein intakes found in studies using self-reported intakes, which is worrisome in the light of the highly prevalent PEM in dialysis patients. Survival analysis showed that creatinine excretion rate could be of interest as a tool for monitoring PEM in dialysis patients. Additionally, for sodium, potassium and phosphate, significant proportional bias was found between both methods. Compared to CBA intake, DA intakes overestimated intake in the lower end of the intakes, while underestimating intake in the higher end of intakes, most notably for sodium. Dialysate and urinary excretion measurements may serve as a more reliable assessment of dietary intake in dialysis patients, as this method is free from the many biases known to self-reported dietary intakes, and may be used as a tool for guiding dietary interventions, using multiple measurements. However, larger studies are warranted to assess the validity, reproducibility, sensitivity and value of this method.

Author Contributions: All authors have substantially contributed to the study and manuscript design, data analyses, data interpretation and/or revision and have approved this final version of the work. The authors have agreed to take accountability for all aspects of this study. The authors' responsibilities were as follows: A.O., R.W., K.J.R.I., S.J.L.B. and C.F.M.F. designed and conducted the research; A.P., S.J.L.B. and C.F.M.F. analyzed the data and performed the statistical analyses; A.P., S.J.L.B. and C.F.M.F. wrote the manuscript and had primary responsibility for the final content; A.P., A.O., R.W., K.J.R.I., S.J.L.B. and C.F.M.F. revised and edited the manuscript. All authors have read and approved the final manuscript.

Funding: The funder of the present study was the Vifor Fresenius Medical Care Renal Pharma Vifor Fresenius Medical Care Renal Pharma had no role in the design, analysis or writing of this article but supported financially.

Conflicts of Interest: None of the authors reported a conflict of interest related to the study. The funders had no role in the design of the study; in the collection, analyses, or interpretation of data; in the writing of the manuscript, or in the decision to publish the results. 


\section{References}

1. Jadeja, Y.P.; Kher, V. Protein energy wasting in chronic kidney disease: An update with focus on nutritional interventions to improve outcomes. Indian J. Endocrinol. Metab. 2012, 16, 246-251. [CrossRef] [PubMed]

2. Bistrian, B.R.; McCowen, K.C.; Chan, S. Protein-energy malnutrition in dialysis patients. Am. J. Kidney Dis. 1999, 33, 172-175. [CrossRef]

3. Kopple, J.D. Pathophysiology of protein-energy wasting in chronic renal failure. J. Nutr. 1999, 129, $247 \mathrm{~S}-251 \mathrm{~S}$. [CrossRef] [PubMed]

4. Mc Causland, F.R.; Waikar, S.S.; Brunelli, S.M. The relevance of dietary sodium in hemodialysis. Nephrol. Dial. Transplant 2013, 28, 797-802. [CrossRef] [PubMed]

5. Zager, P.G.; Nikolic, J.; Brown, R.H.; Campbell, M.A.; Hunt, W.C.; Peterson, D.; Van Stone, J.; Levey, A.; Meyer, K.B.; Klag, M.J.; et al. "U” curve association of blood pressure and mortality in hemodialysis patients. Kidney Int. 1998, 54, 561-569. [CrossRef] [PubMed]

6. Yusuf, A.A.; Hu, Y.; Singh, B.; Menoyo, J.A.; Wetmore, J.B. Serum Potassium levels and mortality in hemodialysis patients: A retrospective cohort study. Am. J. Nephrol. 2016, 44, 179-186. [CrossRef] [PubMed]

7. Block, G.A.; Hulbert-Shearon, T.E.; Levin, N.W.; Port, F.K. Association of serum phosphorus and calcium X phosphate product with mortality risk in chronic hemodialysis patients: A national study. Am. J. Kidney Dis. 1998, 31, 607-617. [CrossRef] [PubMed]

8. Shim, J.S.; Oh, K.; Kim, H.C. Dietary assessment methods in epidemiologic studies. Epidemiol. Health. 2014, 36, e2014009. [CrossRef] [PubMed]

9. Institute of Medicine (US) Committee on Dietary Risk Assessment in the WIC Program. Dietary Risk Assessment in the WIC Program, 5th ed.; National Academies Press: Washington, DC, USA, 2002.

10. Naska, A.; Lagiou, A.; Lagiou, P. Dietary assessment methods in epidemiological research: Current state of the art and future prospects. F1000Res. 2017, 6, 926. [CrossRef] [PubMed]

11. Campino, C.; Hill, C.; Baudrand, R.; Martinez-Aguayo, A.; Aglony, M.; Carrasco, C.A.; Ferrada, C.; Loureiro, C.; Vecchiola, A.; Bancalari, R.; et al. Usefulness and pitfalls in sodium intake estimation: Comparison of dietary assessment and urinary excretion in Chilean children and adults. Am. J. Hypertens. 2016, 29, 1212-1217. [CrossRef] [PubMed]

12. Goncalves, C.; Abreu, S.; Padrao, P.; Pinho, O.; Graca, P.; Breda, J.; Santos, R.; Moreira, P. Sodium and potassium urinary excretion and dietary intake: A cross-sectional analysis in adolescents. Food Nutr. Res. 2016, 60, 29442. [CrossRef] [PubMed]

13. McLean, R.M.; Farmer, V.L.; Nettleton, A.; Cameron, C.M.; Cook, N.R.; Campbell, N.R.C.; TRUE Consortium (International Consortium for Quality Research on Dietary Sodium/Salt). Assessment of dietary sodium intake using a food frequency questionnaire and 24-hour urinary sodium excretion: A systematic literature review. J. Clin. Hypertens. (Greenwich) 2017, 19, 1214-1230. [CrossRef] [PubMed]

14. Ji, C.; Sykes, L.; Paul, C.; Dary, O.; Legetic, B.; Campbell, N.R.; Cappuccio, F.P.; Sub-Group for Research and Surveillance of the PAHO-WHO Regional Expert Group for Cardiovascular Disease Prevention Through Population-wide Dietary Salt Reduction. Systematic review of studies comparing 24-hour and spot urine collections for estimating population salt intake. Rev. Panam. Salud Publica 2012, 32, 307-315. [CrossRef] [PubMed]

15. Potischman, N. Biologic and methodologic issues for nutritional biomarkers. J. Nutr. 2003, 133 (Suppl. 3), 875S-880S. [CrossRef]

16. Morimoto, Y.; Sakuma, M.; Ohta, H.; Suzuki, A.; Matsushita, A.; Umeda, M.; Ishikawa, M.; Taketani, Y.; Takeda, E.; Arai, H. Estimate of dietary phosphorus intake using 24-h urine collection. J. Clin. Biochem. Nutr. 2014, 55, 62-66. [CrossRef] [PubMed]

17. Oterdoom, L.H.; van Ree, R.M.; de Vries, A.P.; Gansevoort, R.T.; Schouten, J.P.; van Son, W.J.; Homan van der Heide, J.J.; Navis, G.; de Jong, P.E.; Gans, R.O.; et al. Urinary creatinine excretion reflecting muscle mass is a predictor of mortality and graft loss in renal transplant recipients. Transplantation 2008, 86, 391-398. [CrossRef] [PubMed]

18. Oterdoom, L.H.; Gansevoort, R.T.; Schouten, J.P.; de Jong, P.E.; Gans, R.O.; Bakker, S.J. Urinary creatinine excretion, an indirect measure of muscle mass, is an independent predictor of cardiovascular disease and mortality in the general population. Atherosclerosis 2009, 207, 534-540. [CrossRef] [PubMed] 
19. Stam, S.P.; Oste, M.C.J.; Eisenga, M.F.; Blokzijl, H.; van den Berg, A.P.; Bakker, S.J.L.; de Meijer, V.E. Posttransplant muscle mass measured by urinary creatinine excretion rate predicts long-term outcomes after liver transplantation. Am. J. Transplant. 2018. [CrossRef] [PubMed]

20. Sinkeler, S.J.; Kwakernaak, A.J.; Bakker, S.J.; Shahinfar, S.; Esmatjes, E.; de Zeeuw, D.; Navis, G.; Lambers Heerspink, H.J. Creatinine excretion rate and mortality in type 2 diabetes and nephropathy. Diabetes Care 2013, 36, 1489-1494. [CrossRef] [PubMed]

21. Hessels, L.; Koopmans, N.; Gomes Neto, A.W.; Volbeda, M.; Koeze, J.; Lansink-Hartgring, A.O.; Bakker, S.J.; Oudemans-van Straaten, H.M.; Nijsten, M.W. Urinary creatinine excretion is related to short-term and long-term mortality in critically ill patients. Intensive Care Med. 2018, 44, 1699-1708. [CrossRef] [PubMed]

22. Ter Maaten, J.M.; Damman, K.; Hillege, H.L.; Bakker, S.J.; Anker, S.D.; Navis, G.; Voors, A.A. Creatinine excretion rate, a marker of muscle mass, is related to clinical outcome in patients with chronic systolic heart failure. Clin. Res. Cardiol. 2014, 103, 976-983. [CrossRef] [PubMed]

23. Du Bois, D.; Du Bois, E.F. A formula to estimate the approximate surface area if height and weight be known. 1916. Nutrition 1989, 5, 303-311. [PubMed]

24. Maroni, B.J.; Steinman, T.I.; Mitch, W.E. A method for estimating nitrogen intake of patients with chronic renal failure. Kidney Int. 1985, 27, 58-65. [CrossRef] [PubMed]

25. Janssen, I.; Baumgartner, R.N.; Ross, R.; Rosenberg, I.H.; Roubenoff, R. Skeletal muscle cutpoints associated with elevated physical disability risk in older men and women. Am. J. Epidemiol. 2004, 159, 413-421. [CrossRef] [PubMed]

26. Cawthon, P.M.; Peters, K.W.; Shardell, M.D.; McLean, R.R.; Dam, T.T.; Kenny, A.M.; Fragala, M.S.; Harris, T.B.; Kiel, D.P.; Guralnik, J.M.; et al. Cutpoints for low appendicular lean mass that identify older adults with clinically significant weakness. J. Gerontol. A Biol. Sci. Med. Sci. 2014, 69, 567-575. [CrossRef] [PubMed]

27. Fielding, R.A.; Vellas, B.; Evans, W.J.; Bhasin, S.; Morley, J.E.; Newman, A.B.; Abellan van Kan, G.; Andrieu, S.; Bauer, J.; Breuille, D.; et al. Sarcopenia: An undiagnosed condition in older adults. Current consensus definition: Prevalence, etiology, and consequences. International working group on sarcopenia. J. Am. Med. Dir. Assoc. 2011, 12, 249-256. [CrossRef] [PubMed]

28. Baumgartner, R.N.; Koehler, K.M.; Gallagher, D.; Romero, L.; Heymsfield, S.B.; Ross, R.R.; Garry, P.J.; Lindeman, R.D. Epidemiology of sarcopenia among the elderly in New Mexico. Am. J. Epidemiol. 1998, 147, 755-763. [CrossRef] [PubMed]

29. Jenab, M.; Slimani, N.; Bictash, M.; Ferrari, P.; Bingham, S.A. Biomarkers in nutritional epidemiology: Applications, needs and new horizons. Hum. Genet. 2009, 125, 507-525. [CrossRef] [PubMed]

30. Ikizler, T.A. Optimal nutrition in hemodialysis patients. Adv. Chronic Kidney Dis. 2013, 20, 181-189. [CrossRef] [PubMed]

31. Kopple, J.D. National kidney foundation K/DOQI clinical practice guidelines for nutrition in chronic renal failure. Am. J. Kidney Dis. 2001, 37, S66-S70. [CrossRef] [PubMed]

32. Burrowes, J.D.; Larive, B.; Cockram, D.B.; Dwyer, J.; Kusek, J.W.; McLeroy, S.; Poole, D.; Rocco, M.V.; Hemodialysis (HEMO) Study Group. Effects of dietary intake, appetite, and eating habits on dialysis and non-dialysis treatment days in hemodialysis patients: Cross-sectional results from the HEMO study. J. Ren. Nutr. 2003, 13, 191-198. [CrossRef]

33. Ovesen, L.; Boeing, H.; EFCOSUM Group. The use of biomarkers in multicentric studies with particular consideration of iodine, sodium, iron, folate and vitamin D. Eur. J. Clin. Nutr. 2002, 56 (Suppl. 2), S12-S17. [CrossRef] [PubMed]

34. Liu, Z.M.; Ho, S.C.; Tang, N.; Chan, R.; Chen, Y.M.; Woo, J. Urinary sodium excretion and dietary sources of sodium intake in Chinese postmenopausal women with prehypertension. PLoS ONE 2014, 9, e104018. [CrossRef] [PubMed]

35. McKeown, N.M.; Day, N.E.; Welch, A.A.; Runswick, S.A.; Luben, R.N.; Mulligan, A.A.; McTaggart, A.; Bingham, S.A. Use of biological markers to validate self-reported dietary intake in a random sample of the European prospective investigation into cancer United Kingdom Norfolk cohort. Am. J. Clin. Nutr. 2001, 74, 188-196. [CrossRef] [PubMed]

36. Anderson, C.A.; Appel, L.J.; Okuda, N.; Brown, I.J.; Chan, Q.; Zhao, L.; Ueshima, H.; Kesteloot, H.; Miura, K.; Curb, J.D.; et al. Dietary sources of sodium in China, Japan, the United Kingdom, and the United States, women and men aged 40 to 59 years: The INTERMAP study. J. Am. Diet. Assoc. 2010, 110, 736-745. [CrossRef] [PubMed] 
37. Espeland, M.A.; Kumanyika, S.; Wilson, A.C.; Reboussin, D.M.; Easter, L.; Self, M.; Robertson, J.; Brown, W.M.; McFarlane, M.; TONE Cooperative Research Group. Statistical issues in analyzing 24-hour dietary recall and 24-hour urine collection data for sodium and potassium intakes. Am. J. Epidemiol. 2001, 153, 996-1006. [CrossRef]

38. Meneton, P.; Galan, P.; Bertrais, S.; Heudes, D.; Hercberg, S.; Menard, J. High plasma aldosterone and low renin predict blood pressure increase and hypertension in middle-aged Caucasian populations. J. Hum. Hypertens. 2008, 22, 550-558. [CrossRef] [PubMed]

39. Meneton, P.; Lafay, L.; Tard, A.; Dufour, A.; Ireland, J.; Menard, J.; Volatier, J.L. Dietary sources and correlates of sodium and potassium intakes in the French general population. Eur. J. Clin. Nutr. 2009, 63, 1169-1175. [CrossRef] [PubMed]

40. Pool, L.R.; Wolf, M. FGF23 and nutritional metabolism. Annu. Rev. Nutr. 2017, 37, 247-268. [CrossRef] [PubMed]

41. Wolf, M. Mineral (Mal)adaptation to kidney disease-Young investigator award address: American society of Nephrology kidney week 2014. Clin. J. Am. Soc. Nephrol. 2015, 10, 1875-1885. [CrossRef] [PubMed]

42. Cupisti, A.; Gallieni, M. Urinary phosphorus excretion: Not what we have believed it to be? Clin. J. Am. Soc. Nephrol. 2018, 13, 973-974. [CrossRef] [PubMed]

43. Sun, Q.; Bertrand, K.A.; Franke, A.A.; Rosner, B.; Curhan, G.C.; Willett, W.C. Reproducibility of urinary biomarkers in multiple 24-h urine samples. Am. J. Clin. Nutr. 2017, 105, 159-168. [CrossRef] [PubMed]

44. Trautvetter, U.; Ditscheid, B.; Jahreis, G.; Glei, M. Habitual intakes, food sources and excretions of phosphorus and calcium in three German study collectives. Nutrients 2018, 10, 171. [CrossRef] [PubMed]

45. Sullivan, C.M.; Leon, J.B.; Sehgal, A.R. Phosphorus-containing food additives and the accuracy of nutrient databases: Implications for renal patients. J. Ren. Nutr. 2007, 17, 350-354. [CrossRef] [PubMed]

46. Moreno-Torres, R.; Ruiz-Lopez, M.D.; Artacho, R.; Oliva, P.; Baena, F.; Baro, L.; Lopez, C. Dietary intake of calcium, magnesium and phosphorus in an elderly population using duplicate diet sampling Vs food composition tables. J. Nutr. Health Aging 2001, 5, 253-255. [PubMed]

47. Oenning, L.L.; Vogel, J.; Calvo, M.S. Accuracy of methods estimating calcium and phosphorus intake in daily diets. J. Am. Diet. Assoc. 1988, 88, 1076-1080. [PubMed]

48. Sherman, R.A.; Mehta, O. Dietary phosphorus restriction in dialysis patients: Potential impact of processed meat, poultry, and fish products as protein sources. Am. J. Kidney Dis. 2009, 54, 18-23. [CrossRef] [PubMed]

49. Carrigan, A.; Klinger, A.; Choquette, S.S.; Luzuriaga-McPherson, A.; Bell, E.K.; Darnell, B.; Gutierrez, O.M. Contribution of food additives to sodium and phosphorus content of diets rich in processed foods. J. Ren. Nutr. 2014, 24, 13-9. [CrossRef] [PubMed]

50. Tosato, M.; Marzetti, E.; Cesari, M.; Savera, G.; Miller, R.R.; Bernabei, R.; Landi, F.; Calvani, R. Measurement of muscle mass in sarcopenia: from imaging to biochemical markers. Aging Clin. Exp. Res. 2017, $29,19-27$. [CrossRef] [PubMed]

(C) 2018 by the authors. Licensee MDPI, Basel, Switzerland. This article is an open access article distributed under the terms and conditions of the Creative Commons Attribution (CC BY) license (http://creativecommons.org/licenses/by/4.0/). 